\title{
Issuance Legality of the Ownership Certificate for the Riparian Area and Its Legal Consequences in Sukoharjo Regency
}

\author{
Argo Sri Hutomo*; Lego Karjoko
}

Faculty of Law UNS, Universitas Sebelas Maret

Email: argohutomobakrie@gmail.com

http://dx.doi.org/10.18415/ijmmu.v5i2.328

\begin{abstract}
The article aims to analyze and find out the legality of the issuance of a Certificate of Property in the river border and the legal implications for those issuing and holding a Certificate of Ownership in the river border in Sukoharjo District. Research method with a normative juridical approach. The technique of collecting data which study of library. The result of the research of the land rights certificate of riparian area in Sukoharjo regency is possible the abuse of authority of the National Land Office of Sukoharjo Regency issuing the certificate of property right without taking into account other legal provisions. By law the issuance of the boundary rights certificates of rivers in Sukoharjo District remains valid, but legally flawed. River border property rights certificates can be canceled if there is a demand from the public by filing a lawsuit to the State Administrative Court. The ownership certificate in the river border can not be used as collateral or as a strong evidence against the certificate. The certificate of title to land in the river border in Sukoharjo regency, indicates the principle of prudence has not been implemented properly in the issuance of certificates of land rights. There needs to be more intensive supervision on the issuance of certificates of ownership of riparian area soil and more assertive to consolidate the soil that should be a watershed so that the function of river border which is a protected area will be maintained and the creation of a pattern of utilization of space in accordance with its purpose
\end{abstract}

Keywords: Legality; Certificate of Ownership; River Border; Legal Effect

\section{Introduction}

The ownership certificate of the riparian area in Sukoharjo Regency becomes a problem, not only for the certificate holder but also for the issuer of the certificate. From the certificate holder viewpoint, the issuance of the certificate generates a legal problem since a riparian area is a land owned by the state and cannot be owned personally, so the issuance of the ownership certificate possibly violates the law. By the certificate issuance process which is not under the regulation, its legality may be questionable.

Based on the background described above, the legality of the Ownership Certificate of riparian area in Sukoharjo Regency will be discussed. Moreover, what is the legal implication for the issuer and holder of the certificate of riparian area in Sukoharjo Regency? 


\section{Methodology}

The design of this research is normative juridical, and it aimed to analyze all laws and regulations related to the legal issues being discussed. Statute approach is an approach by using legislation and regulation ${ }^{1}$.

The researcher used normative legal research to generate new argumentation, theory, or concept as a prescription to solve issues being faced. In addition, this research identified the legality of the issuance of ownership certificate of the riparian area in Sukoharjo Regency and the legal implication for the issuer and the holder of the ownership certificate of the riparian area in Sukoharjo Regency. The analysis is based on article 2 of Sukoharjo Regional Regulation no. 14 of 2011 about the spatial zoning plan of Sukoharjo regency in 2011-2031 and the article 3 of law no.11 of 1974 about irrigation, law no.23 of 2014 about local government, and article 2 and 3 paragraph (2) of the Government regulation no 25 of 1991 about a river, article 1 paragraph (2) of regional regulation of Sukoharjo regency no. 2 of 2015 about the amendment of local regulation no. 5 of 2011.

In this study, secondary data become the source and material of law. Secondary data is data obtained from the literature study in the form of legal materials ${ }^{2}$. The legal material of this research consists of Law no.5 of 1960 about Agrarian Law, the law no.11 of 1974 about Irrigation, law no.23 of 2014 about local government, Regulation of the Ministry of Public work and Public Housing of Indonesia no.28/Prt/M/2015 about the decision of the river and the lake riparian border, Regional Regulation of Sukoharjo Regency no. 12 of 2012 about Spatial Zoning Plan of Sukoharjo Regency for 2011 until 2031, and the Regional Regulation of Sukoharjo regency no.2 of 2015 about the amendment of Regional regulation no. 5 of 2011 about Building. Since this research focused on the secondary data, the data collection was done by literature and document study.

\section{Results and Discussion The legality of Ownership Certificate of Riparian Area in Sukoharjo Regency}

Registering a land in order to gain a certificate shall be following the principle of law. There are some principles of land registration used to warrant legal certainty in a land registration Registration of land/ right of land performed under the regulation of Agrarian law and the Government Regulation no. 10 of 1961 about land registration uses the principle of publicity and the principle of specialty. The principles of publicity are reflected by juridical data regarding the right over lands such as the subject of the right, the name of the right, transfer, and the imposition of the right. While, the principles of specialty are reflected by the physical data regarding the land right such as the breadth of a land, the location of the land, and the firm stipulation of a land border. These principles are laden in a general list, and it is allowed for anyone who is willing to find out about these principles.

The legal issue emerges from the enforcement of these principles is when the Sukoharjo Government allows the community on the riparian area to own a land certificate in National Land Affairs Body (BPN). This policy, of course, is not appropriate since establishing a house in the riparian area interferes the environment, violates the law, and is unjust. That policy violates the Law of Environment and Government Regulation of River. Article 37 paragraph 1 Law no. 23 of 1997 about Environment states: " People hold rights to file a lawsuit to a court and/ or to report to the law enforcer about any problem concerning the environment that harms public life.". Government Regulation no. 35 of 1997 about a river, especially article 5 (1) and (2).

\footnotetext{
${ }^{1}$ Peter Mahmud Marzuki. (2010). Penelitian Hukum, Jakarta: Kencana
}

${ }^{2}$ Soerjono Sukanto. (1990). Metode Penelitian Hukum, Jakarta: UI Press 
Riparian area in Sukoharjo Regency is the state' land owned by the Regional Government of Sukoharjo, on that land, no party may possess that land except the Regional government of Sukoharjo. The consideration basis of the issuance of the ownership certificate of such land is that the applicant has settled on that land for a long time, the applicant is willing to be arranged to prevent slum. Based on the city planning team measurement, the area is located outside the riparian area, the applicant has adhered the regulation and is able to carry out his/her responsibility, the area is feasible for the settlement; the area can be more productive in increasing Sukoharjo' local own-source revenue, the area possesses hard soil contour; it is safe from floodplain and does not jeopardize other areas; based on the spatial zoning plan, the function of that area is river embankment. Another consideration of the issuance is that such land possesses strategic values, it contains not only physical aspect but also the social, economic, political, and legal aspect. Land resource possesses six kinds of values, namely: 1) productive value; 2) location value; 3) environmental value; 4) social value; 5) political value, and 6) legal value. A land resource is perfect if it meets these values. The imperfection of a land value will lead to unequal and injustice mechanism of land allocation. A group of community who own high access tends to exploit such imperfection for their own benefits. Therefore, the Government' role in managing a land resource is pivotal. That role should not only be limited to the attempt to perfect the mechanism of land resource allocation. More than that, It needs an institution to carry out the function above so that the land can be utilized in more prosperous, fair, and equal manner. A community who has asked permission to utilize the land in the river area which its authority is given to the Regional Government of Sukoharjo, is given by the governor of Central Java by a technical recommendation from the related Office after consulting with the head of Land Affairs Office of Sukoharjo Regency.

The land management in Sukoharjo Regency possesses constitutional foundation based on the article 33 paragraph (3) of 1945 constitution which states " The land, the waters, and the natural resources within shall be under the powers of the State and shall be used to the greatest benefit of the people." Article 33 paragraph (3) of 1945 Constitution is translated into Law no.5 of 1960 about the basic regulations on agrarian principles that contains the national land policy which becomes the basis of land management in Indonesia. On land management, particularly those related to the management of land ownership management and land rights, a land registration institution is needed to provide legal certainty between the right holder and the land, the land' right transfer, the land security title, and the security title transfer. Furthermore, land registration is a source of information to decide on land management either in the regulation of authority, ownership, or utilization of land.

The issuance of land ownership certificate of the riparian area in Sukoharjo also grounded on the article 2 of Regional Regulation of Sukoharjo Regency no.14 of 2011 about spatial zoning plan of Sukoharjo Regency for 2011-2031, it is stated that the spatial planning of Sukoharjo Regency aims at establishing a zone that relies on green industrial sector and the infrastructure development to enhance accessibility.

The enforcement of the Regulation of Minister of Public works and Public Housing no.28/Prt/M/2015 about the decision of river and lake riparian, specifically in article 5, states that: Unembanked riparian line in urban area as meant by article 4 paragraph (2) clause a, is considered as at least 10 (ten) meters from the left and right side of the river trench along the river flow, in case of the river depth is less than or equal to 3 (three) meters; at least 15 (fifteen) meters from the left and right side of the river trench along the river flow, in case of the river depth is more than or equal to 3 (three) meters upto 20 (twenty) meters; and at least 30 (thirty) meters from the left and right side of the river trench along the river flow, in case the river depth is more than 20 (twenty) meters.

Article 24 of Regulation of the Ministry of Public Works and Public Housing of Indonesia no. 28/PRT/M/2015 about the decision of lake and river riparian, utilization of the riparian as meant by article 22 and 23 is carried out under the permission from the Minister, governor, or regent/ mayor in accordance 
to its authority regarding the water resource management. Such permission is given by considering the technical recommendation from the water resource manager of the respective river.

The control on the land ownership certificate issuance is a sequence of attempts made to evaluate the land ownership certificate issuance to keep it corresponds to the regulation and to avoid deviation, and to correct the deviation.

The land disputes or conflicts occur lately is not only caused by legally unregistered land but also is caused by the registered land. This fact shows that evidentiary instrument in the form of certificate (land certificate) does not warrant the strength of a person or a legal body' right to the land. A land certificate contains physical and juridical data that must be accepted as a truth, either in daily legal activity or a dispute in a court. The data contained within the certificate shall be in line with the survey document and the land book. Furthermore, a person or a legal body cannot sue a certified land on behalf of other person or legal body if, during 5 (five) years since the issuance of that certificate, that person or legal body does not file a lawsuit in a court. While, such land is possessed by a person or a legal body by goodwill and physically owned by them, or other person or legal body authorized by them.

The issuance of an ownership certificate of the riparian area in Sukoharjo area occurs because of the issuer' lack of material requirement. They issue an ownership certificate without considering other regulations, in this case, they disregard regulation, especially law no. 26 of 2007 about Spatial Planning Same thing happened when the community owned the riparian area, and it violated the Regional Regulation no. 10 of 2011 about the spatial zone planning of Bandar Lampung City. The riparian area is a green area, and it is not used for housing as the community has done ${ }^{3}$. Whereas, this law has mandated all provinces, regency, and city to possess a spatial zone planning as a reference in carrying out the development. The violation of law about the spatial zoning is caused by the weak law enforcement, so the community does not care about that regulation. Furthermore, in Government Regulation no. 38/2011 about river affirms that 10-20 meters from the river edge are forbidden to be built. River, including riparian area, is owned by the State. However, the land encroachment still occurs. The government lets the state' land being encroached, even being owned by personal. Many citizens hold ownership certificate of the riparian area issued by the Land Affair Office of Sukoharjo Regency. In this element, it does not matter whether a function which acts only from the executive field apparatus. Theoretically, apparatus from the legislation field and the court field can do a governmental action which nature is stipulation. The consequence of the act in this function is the emergence of right and obligation on the other person. The stipulation that leads to right and obligation is called as a positive stipulation, for instance, the issuance of the land certificate that gives a right to a person whose name is listed within that certificate to use that land and put an obligation in the form of tax payment over that land.

Such legal action is considered as unilateral since it depends on the authorized body or the officer to do so. The officer in that function does not carry out his/ her willingness, he/ she perform obligation based on his/her function authority. In this case, he/ she consciously act based on the obligation of his/her function. The authority of such function allows he/ she to decline the application. So, in this case, his/her willingness takes a role based on the functional authority. That act is based on the special authority given by the constitution only for the state government/ administration and is not given to the legislative and judicial body. On the other hand, if a governmental body holds a nexus with a citizen and in that nexus, these two parties' status is equal, so that governmental body does not act concerning its special authority.

\footnotetext{
${ }^{3}$ Himawaty Kusumaningtyas. (2014). Tatus Penguasaan Tanah Oleh Masyarakat Di Sepanjang Daerah Aliran Sungai Di Kota Bandar Lampung, Jurnal Ilmiah Hukum Administrasi Negara, Vol. 1, No 1 (2014).
} 
The stipulation standard in the issuance of land ownership certificate is needed as a guideline, so the issued certificate can be legally accountable and is in accordance with the standard in force. The stipulation standard in the issuance of land ownership certificate on the Land affairs office of Sukoharjo Regency comprises the standard operating procedure of the land ownership certificate issuance, procedure in the land ownership certificate issuance, and the authorized officer in permitting right of ownership. The violation concerning the process of land ownership certificate of the riparian area in Sukoharjo done by the Land affairs office of Sukoharjo regency leads to the hesitation of the validity of such ownership certificate.

The existence of the ownership certificate of the riparian area can be legally annulled if there is a complaint from the community. The community can sue the Sukoharjo Government since that policy violates the Law of Environment and The government regulation of a river. Article 37 paragraph 1 Law no. 23 of 1997 about Environment states: "The community shall have the right to file a lawsuit in representation to the court of law and/or report to law enforcers various environmental problems harming the life of the community." Land in the riparian area is forbidden to be personally owned since its status is the green area. It is stated that the stipulation of river area involves a river area located in a district/ municipality, river area located across the districts/municipalities, river area located across the provinces, river area located in a cross-country, and national strategic river area.

The community who refuse the land certification on the riparian area also refers to the article 12 of Government regulation no. 16 of 2004 about the land use which states that the land from the arising soil or the reclamation result in the coastal water, tidal land, swamp, and the ex-river is directly owned by the state, so the community does not have right to get the land certificate in the riparian area.

The community' complaint towards the legality of the issuance of ownership certificate of riparian area is filed to the State Administrative Court concerning the land ownership or certificate issuance. By this complaint, the community will gain legal protection regarding the legality of ownership certificate, especially in the public area.

\section{The Legal implication for the Holder and the Issuer of the Ownership Certificate of the Riparian Area in the Sukoharjo Regency}

Many ownership certificates of the riparian area in Sukoharjo Regency showed that land ownership certificate issued by the Land affairs office of Sukoharjo Regency could not give a legal warranty or legal certainty, or become a robust evidentiary instrument towards the issued certificate. This is, of course, become a complicated legal issue when the same thing happens in the future. To overcome this issue, the Land Affairs Office of Sukoharjo Regency, in carrying out its function and duty, especially regarding the certificate issuance, should perform the principles of prudence. In other words, It should implement all legal provisions and regulations in force. This is supported by the existence of some problems faced during the giving of the right of ownership over the state' land and its registration. It is caused by the community' low level of understanding who live on the state' land, and lack of the applicant data completeness, either physical or juridical data. Furthermore, it is also caused by a fee which is not in accordance with the regulation and lack of Land affairs office' human resource ${ }^{4}$.

Referring to three points mentioned above, the writer opines that the procedural mistake during the process of the land right stipulation and/or registration as the basis to rescind the land ownership certificate without a court decree is difficult if it contains a dispute and still needs advanced evidence

\footnotetext{
${ }^{4}$ Pandu Eka Pramudya. (2016). Pelaksanaan Pendaftaran Hak Milik Atas Tanah Negara di Surakarta (Studi di Kantor Pertanahan Kota Surakarta. Jurnal Repertorium, Volume III No. 2 Juli-Desember 2015:
} 
regarding the basic truth of the of such annulment, and the attempt made by the Land Affairs Office, in this case, is by suggesting to the court. This is in line with the legal principles of the State Administration which state that the applicant should be given an opportunity to file a lawsuit to the court. The State Administration dispute should be caused by the decree of Administrative Court since there should be a cause and effect relationship. Without the State Administrative Court decree, there will be no State administration dispute. So, The Government Regulation no. 24 of 1997, in article 32 paragraph (2) provides an opportunity for the parties who think they possess more rights, to prove themselves as the rightful owner of the land, so anyone who wins in the court possesses legal certainty ${ }^{5}$.

The procedural mistake during the process of right stipulation and/ or regulation can be the basis of right annulment without the court decree only if it does not involve two parties in dispute and the right holder ask to do so because he/she finds a mistake during the process, for instance, a right holder finds that a land he/ she register is being processed to be given a right, while, during filing the application, he/she attach the proof that it is a former customary land. However, another problem needs to be concerned is, " if the right annulment is performed, does this mean that the registration process under the correct procedure shall be repeated?". How the National Land Affairs Body is responsible to this problem, Is the National Land Affairs Body ready to cover the re-registration fee? Consequently, this administrative defect category needs advanced regulation related to the mechanism of annulment, and the consequences emerge from it.

Procedural mistakes during the registration of right transfer and/ or the substituting certificate also need regulation clarity. What kind of mistakes meant during this process. When a person files a right annulment caused by mistakes during the registration of right transfer and/ or the substituting certificate and involves a dispute between two parties, the repetition of the transfer process or certificate substitution needs a regulation concerning the potential consequences occurs because of that annulment. As well as the other types of defects such as procedural mistake during the process of the stipulation and/or the admission of right over a former customary land, right overlapping, land ownership certificate, or the mistakes on the subject of the right and/or the object of the right. For administrative defect caused by the incorrect result of the measurement, the writer suggests that it does not need a certificate annulment, it is enough by revising the data without rescinding the certificate.

\section{Conclusion}

The Ownership Certificate of the riparian area in Sukoharjo Regency emerges because of Sukoharjo Regency Land Affair Office' lack of the material requirement who issues an ownership certificate without considering other laws. In this case, it violates the Regulation of Ministry of Public Works and Public Housing no. 28/prt/2015 on the river and lake riparian border. From the legal viewpoint, the issuance of ownership certificate of the riparian area in Sukoharjo Regency is illegal since it does not meet the material requirement. Moreover, the ownership certificate of the riparian area can be rescinded if the holder of the ownership certificate of that riparian area files a lawsuit to the State Administrative Court.

The standing of the ownership certificate of the riparian area issued by the Land Affair Body of Sukoharjo Regency cannot be used as a legal warranty and legal certainty or become a strong evidentiary instrument towards the issued certificate. This is, of course, become a complex legal issue when the same thing happens in the future. A land certificate holder will feel safe about his/her land right certainty since if there is a violation over his/her land, the landowner may claim his/ her right back. Therefore, the

\footnotetext{
${ }^{5}$ Yuyun Mintaraningrum. 2015. Aspek Kepastian Hukum Dalam Penerbitan Sertifikat Hak Tanah (Analisis Putusan Pengadilan Tata Usaha Negara Semarang Nomor Putusan PTUN Nomor 24/G/TUN/2000/PTUN.Smg) Jurnal Repertorium, ISSN:2355-2646, Volume II No. 2 Juli - Desember 2015.
} 
community who hold the land certificate of the riparian area may file a lawsuit to the State administrative court concerning their land ownership.

\section{Suggestion}

The ministry of Public work and Public Housing, or Sukoharjo Government should maintain the riparian area; it is essential since the riparian area is one of the areas which may not be owned by personal.

Sukoharjo Government should be more assertive in enforcing Law no.51 PRP of 60, if there is an illegal settlement in the riparian area, it should be evicted immediately to maintain its sustainability, so the pattern of spatial utilization will be following its purpose.

Land ownership certificate issued by the Land Affairs Office of Sukoharjo Regency is not an absolute evidentiary instrument since it can be rescinded by the court. Accordingly, The Land Affairs Office of a Regency or Town should carefully verify the issuance requirement of a land ownership certificate applied by the applicant, so there will be no annulment in the future.

\section{References}

A. P. Parlindungan. (1999). Pendaftaran Tanah Indonesia, Bandung: Mandar Maju.

Hermit. (2004). Cara memperoleh sertifikat tanah hak milik, tanah Negara dan tanah PEMDA, Bandung: Mandar Maju.

Himawaty Kusumaningtyas. (2014). Tatus Penguasaan Tanah Oleh Masyarakat Di Sepanjang Daerah Aliran Sungai Di Kota Bandar Lampung, Jurnal Ilmiah Hukum Administrasi Negara, 1(1): 2014.

Indroharto. (2002). Usaha Memahami Undang-Undang Tentang Peradilan Tata Usaha Negara, Jakarta: Pustaka Sinar Harapan.

Lexy Maleong. (2006). Metode Penelitian Kwalitatif, Edisi Revisi, Bandung: PT. Remaja Rosdakarya.

Lintong Oloan Siahaan. (2000). Wewenang PTUN Menunda Berlakunya Keputusan Pemerintah, Jakarta: PT. Percetakan Negara RI.

Lubis, Mhd. Yamin dan Abd. Rahim Lubis. (2010). Hukum Pendaftaran Tanah, Bandung: CV. Mandar Maju.

Muchsan. (2007). Sistem Pengawasan Terhadap Perbuatan AparatPemerintah dan Peradilan Tata Usaha Negara di Indonesia, Yogyakarta: Liberty.

Natalia, Njoo Novi. (2007). Penyelesaian Hukum Terhadap Penerbitan Sertipikat Hak Atas Tanah Yang Cacad Hukum Administratif Di Kantor Pertanahan Kota Semarang. Thesis, Program Pascasarjana Universitas Diponegoro.

Pandu Eka Pramudya. (2016). Pelaksanaan Pendaftaran Hak Milik Atas Tanah Negara di Surakarta (Studi di Kantor Pertanahan Kota Surakarta. Jurnal Repertorium, Volume III No. 2 Juli-Desember 2015. 
Patrick, McAuslan. (1986). Tanah Perkotaan Dan Perlindungan Rakyat Jelata, Jakarta: PT. Gramedia.

Peter Mahmud Marzuki. (2010). Penelitian Hukum, Jakarta: Kencana.

Soerjono Sukanto. (1990). Metode Penelitian Hukum, Jakarta: UI Press.

Sriyanti Achmad. (2008). Pembatalan Dan Penerbitan Sertipikat Hak Atas Tanah Pengganti (Studi Kasus Pembatalan Sertipikat Putusan MA No. 987 K/Pdt/2004)" Tesis, Magister Kenotariatan Program Pascasarjana Universitas Diponegoro Semarang.

Suparno. (2005). "Pelaksanaan Permohonan Hak Atas Tanah Di Sekitar Bantaran Sungai Di Kota Surakarta. Tesis, Magister Kenotariatan Program Pascasarjana Universitas Diponegoro Semarang.

Yuyun Mintaraningrum. (2015). Aspek Kepastian Hukum Dalam Penerbitan Sertifikat Hak Tanah (Analisis Putusan Pengadilan Tata Usaha Negara Semarang Nomor Putusan PTUN Nomor 24/G/TUN/2000/PTUN.Smg) Jurnal Repertorium, ISSN:2355-2646, II(2) Juli - Desember 2015.

\section{Copyrights}

Copyright for this article is retained by the author(s), with first publication rights granted to the journal.

This is an open-access article distributed under the terms and conditions of the Creative Commons Attribution license (http://creativecommons.org/licenses/by/4.0/). 